\title{
Assessment of geohazards and management of their possible impacts in the Kurbini region, Albania
}

\author{
Arjan BEQIRAJ ${ }^{*}$, Fran GJOKA², Mentor LAMAJ ${ }^{3}$ \& Majlinda CENAMERI ${ }^{4}$ \\ ${ }^{1}$ Department of Earth Sciences, Polytechnic University of Tirana, Albania \\ ${ }^{2}$ Department of Agro-Environment, Agricultural University of Tirana, Albania \\ ${ }^{3}$ Geological Survey of Albania, Tirana, Albania \\ ${ }^{4}$ Department of Applied Geology, Geo-informatics and Environment, Polytechnic University of Tirana, Albania
}

Received March 2009; accepted July 2009

Available online September 2009

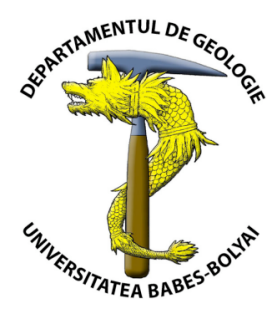

\begin{abstract}
The small region of Kurbini, situated in the north western part of Albania, faces various hazards, due to the particular geographical position marked by the close neighbourhood of the high mountains and the Adriatic Sea. The hydrological and hydrogeological hazards, the deterioration of the groundwater quality, the intense erosion of the soil, the local acidification/contamination/salinization of the soil, and the desertification of land, are the most important geohazards threatening the area. A complex monitoring of all identified risk factors is necessary in order to avoid catastrophic events and irreversible damages.
\end{abstract}

Key words: geohazard, flood, erosion, desertification, Albania.

\section{INTRODUCTION}

The region of Kurbini is a small area in north-western Albania (Fig. 1), where eastern mountains and western coastal areas merge (Fig. 2). The mountains consist of Cretaceous limestone and Oligocene flysch, whereas the Neogene molasse and Quaternary sediments outcrop on the hills and along the plain, respectively. The erosion concerns mainly the mountainous and hilly reliefs and to a less extent the river banks and coastline, whereas the plain was often affected by floods. Consequently, this caused on one hand the soil desertification and on the other hand, water saturation, thus reducing soil fertility. The coastal artesian aquifer of Fushe Kuqe, that occurs beneath the plain of the Kurbini region, represents the most important alluvial aquifer of Albania (Tartari and Dakoli, 2001). Due to hydraulic connection with sea water, the southern part of the aquifer contains saltwater. The increasing rates of the ground-water pumping have driven the saltwater intrusion towards the inner parts of the aquifers (Beqiraj et al., 2002).

\section{GEOLOGICAL SETTING}

The limestone and flysch formations in the Kurbini region, that belong to Kruja tectonic zone, are westward overthrust in accordance with the regional tectonic style of the Albanian geological structures (Melo and Shallo, 1991). The Neogene formations of the Pre-Adriatic depression are mainly composed of clay and sandstone which are transgresively placed on the older formations. The Quaternary sediments, covering all the plain, consist of alternating and discontinuous layers of gravels, sands, silts and clays. Their thickness ranges from $50-60 \mathrm{~m}$ in the southern part up to $180-200 \mathrm{~m}$ in the north-western part of the area. The alluvial gravels and sands are saturated with fresh water which occurs in confined conditions as an artesian aquifer, due to a thick (30-50 m) clay and silty clay covering layer (Eftimi et al., 1989).

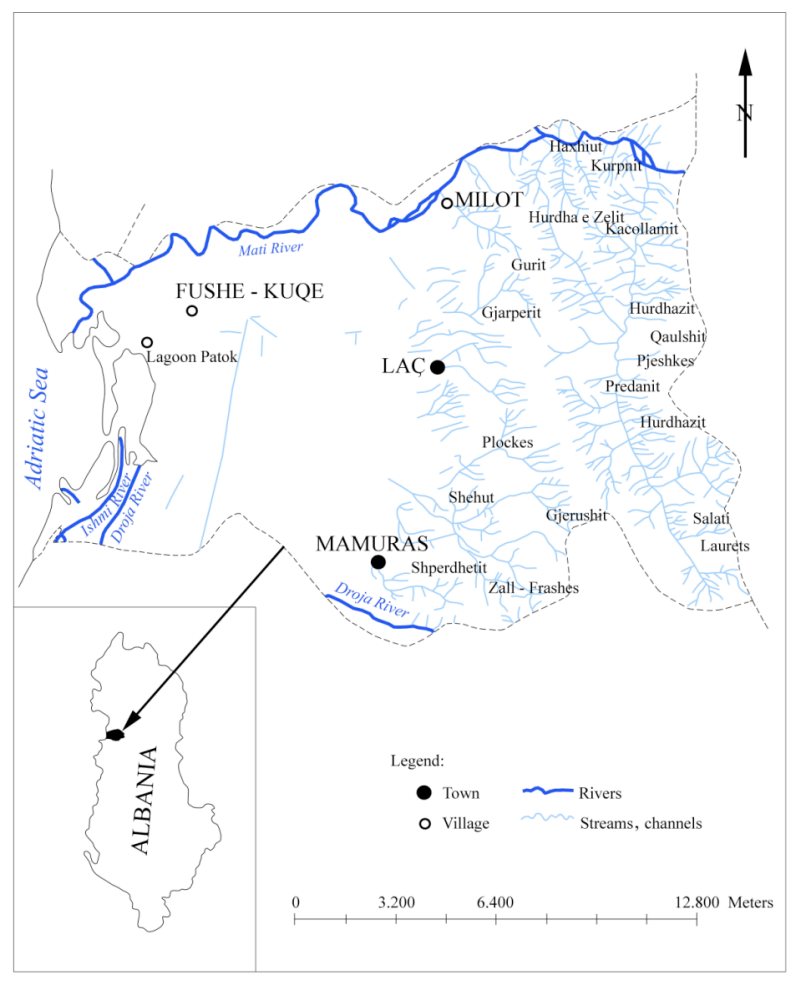

Fig. 1. The administrative map of the Kurbini region (Albania). 


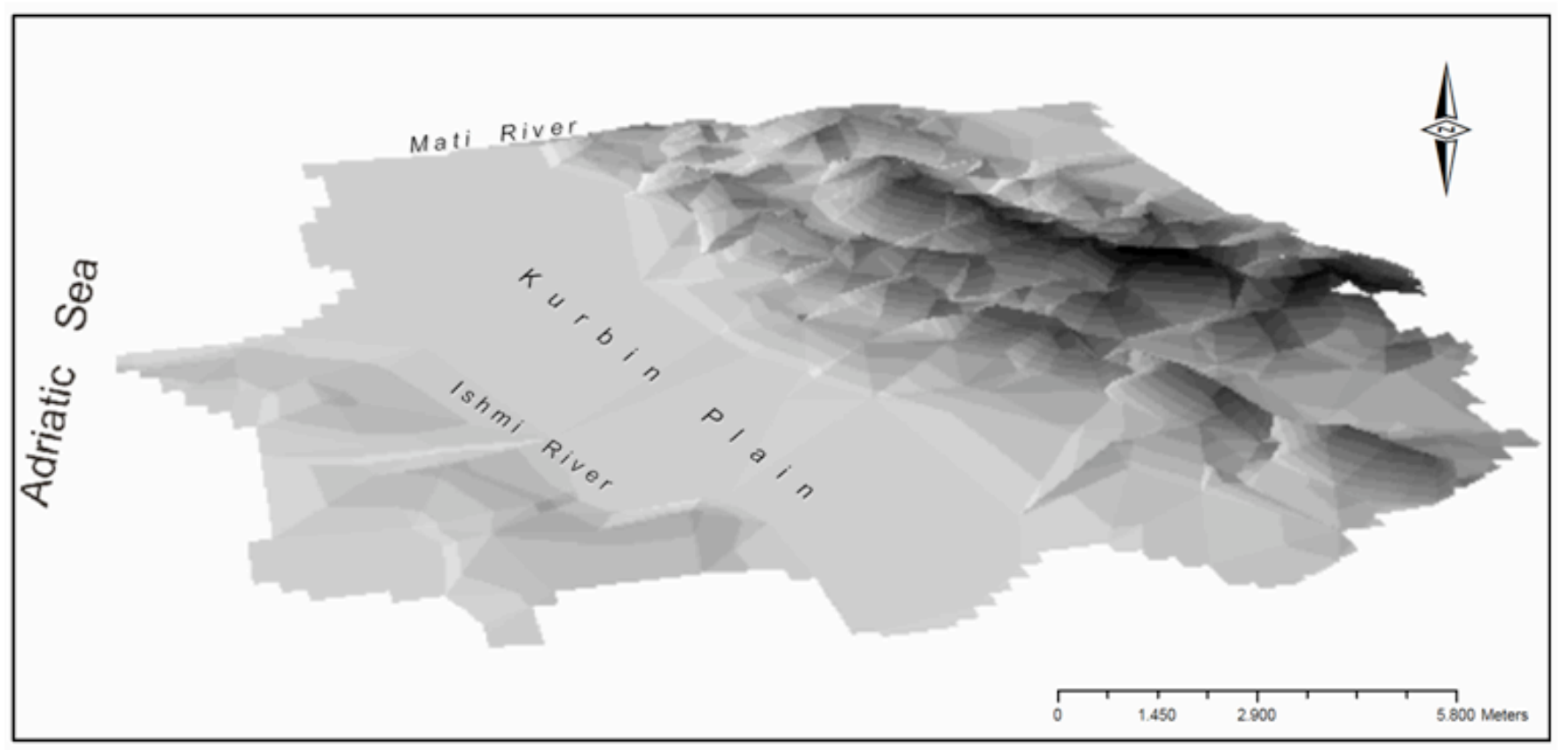

Fig. 2. 3D sketch of the Kurbini region morphology (according to Suljoti et al., 2002).

\section{HYDROLOGICAL HAZARDS}

The principal hydrological components of the Kurbini region are the Mati and Ishmi rivers, the Adriatic Sea and the Patoku lagoon. The Ishmi and Mati rivers mark the southern and northern limits of the region. According to Pano (1981), the flow of the Mati river ranges from 55 to $185 \mathrm{~m}^{3} / \mathrm{s}$, during the dry and wet period, respectively. Occasionally, it reaches extremely high values, close to $3100 \mathrm{~m}^{3} / \mathrm{s}$ (Pano, 1981). The mass of alluvium transported by the Mati river towards its delta and in the Adriatic Sea is about 2.02 million tons per year (Sulçe et al., 2006). The dynamic accumulative character and the weak subsidence trend are similar to other coastal regions of the Adriatic Sea (Marabini, 1985).

The heavy rainfalls from the last twenty years produced several severe floodings in the Kurbini plain. The mountainous catchment area, the very short, 10 to $15 \mathrm{~km}$ long, course of the rivers and, the malfunction of the drainage system favoured these events (Sulçe et al., 2006). The artificial deepening and widening of the Mati river bed and the enhancement of the drainage system will most likely attenuate or completely avoid any flood and their consequences.

\section{HYDROGEOLOGICAL HAZARDS}

Since Holocene, the territory of Kurbini has undergone a differential erosion process which developed various geomorphological features (Sulçe et al., 2006). The erosion mostly involved the flysch formations and, in particular, the eluvial soft sediments. The erosional rates depend in fact on both the lithology of outcropping formations, the regional hydrological factors, such as intensity of precipitations, speed of surface water flow, and geomorphological characteristics, e.g slope inclination.

Based on the previous studies (Sulçe et al., 2006), a lowering of the earth surface that ranges from 0.03 to 0.04 $\mathrm{mm} / \mathrm{year}$, on the hilly and mountainous terrains, respectively, was estimated. This represents a consequence Studia UBB, Geologia, 2009, 54 (2), 9 - 12 of the common action of the chemical weathering and physical alteration of the geological formations that, in turn, have been moved away by erosion energy of the surface water. Along the plain, the accumulation by the river flow prevails over erosion and the horizontal component of the erosion over the vertical one. This later one prevails along the hilly and mountainous water courses, where narrow and deep valleys are shaped. Transversal dams should be constructed to lower rates of streambed erosion, whereas the sowing of the plants over the slopes will prevent the earth surface erosion.

Deterioration of the groundwater quality regards the main water source in the area, i.e. Fushe Kuqe artesian aquifer. There are three main causes of this process: i) the intensive excavation of the bed gravels of the Mati river, which is considered to be one of the main recharge sources of the Fushe Kuqe artesian aquifer, while the second is represented by eastern Cretaceous limestones; ii) the farming, with the use of chemical fertilizers and pesticides; iii) the infiltration of sea water. The last factor represents not only the real geohazard for the Fushe Kuqe coastal aquifer, but it is also the main factor of groundwater contamination by salt (Beqiraj et al., 2002). Because of large quantities of groundwater pumped from the aquifer since 1964, when the first hydrogeological wells were drilled, the natural interface between the salt water and fresh water was gradually moved into the aquifer (Fig. 3). Before that time the freshwater and seawater were under natural conditions, thus, the seaward movement of freshwater prevented saltwater from encroaching the aquifer, and the interface between freshwater and saltwater was maintained near the coast. For seawater intrusion, salt water/fresh water interface can be computed with two alternative models: the first model postulates the existence of a sharp interface separating the fresh and salt water, while the second one explicitly accounts for the existence of a transitional zone (Kacimov and Obnosov, 2001). Since 1964, a high number of public wells are pumping about $1,000 \mathrm{~m}^{3} / \mathrm{s}$ water. Another 1,000 $\mathrm{m}^{3} / \mathrm{s}$ water comes from private wells intersecting the Fushe Kuqe artesian aquifer (Tartari and Dakoli, 2001). 


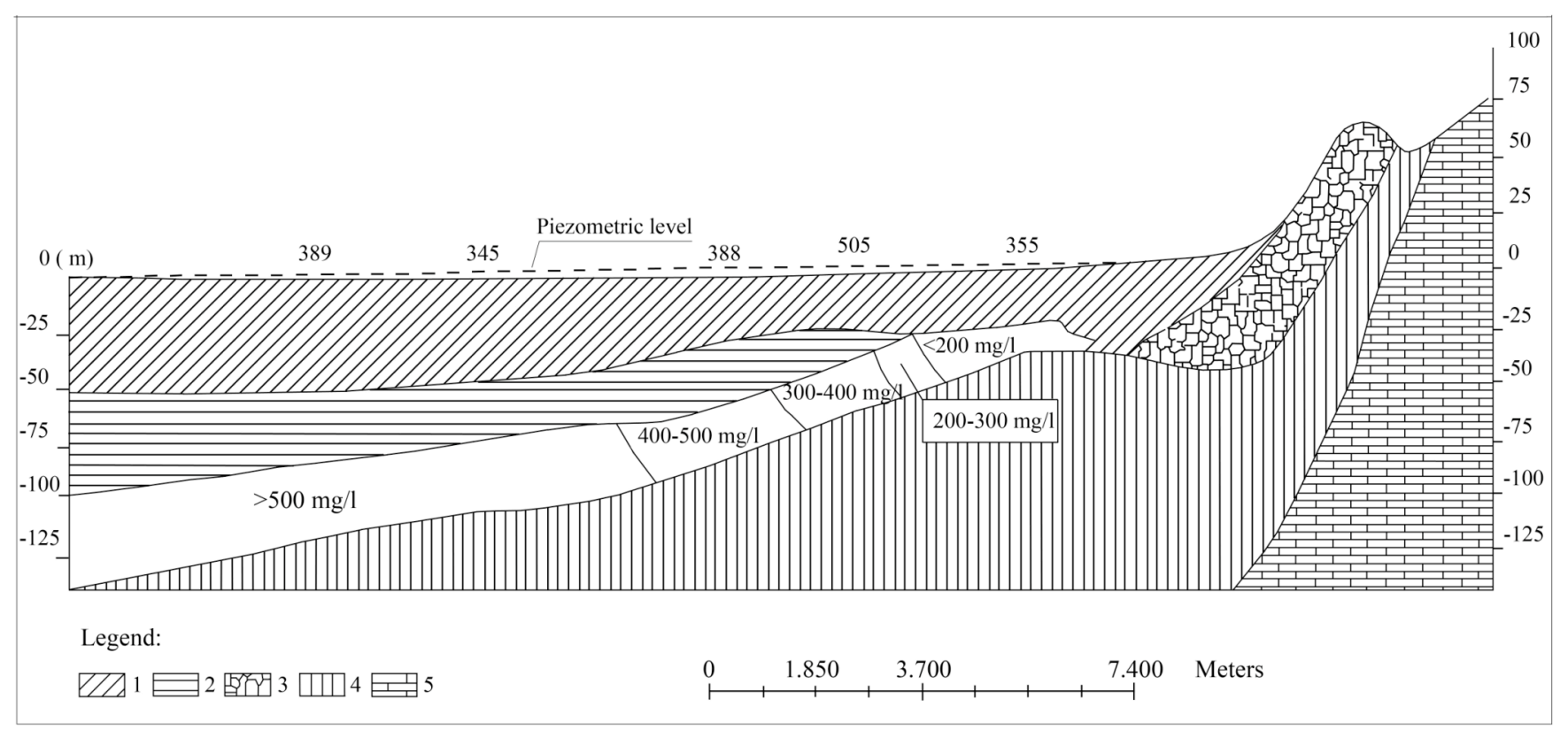

Fig. 3. Intrusion of sea water towards the fresh water aquifer. Legend: 1 - Sandy clay, 2 - Clay, 3 - Conglomerate, 4 - Silt, 5 - Limestone. The white field represents the aquifer layer; the values in $\mathrm{mg} / \mathrm{l}$ refers to chlorine concentration; from Beqiraj et al., 2002).

On the other hand, the calculated natural groundwater flow is around $4.5-5.0 \mathrm{~m}^{3} / \mathrm{s}$ (Tartari and Dakoli, 2001). The increase of the groundwater usage (Table 1) decreased the freshwater flow towards the coastal discharge areas and thus caused the infiltration of saltwater (Table 2) (Pano and Saraçi, 2000). The clearest evidence of the groundwater pressure reduction is the lowering of the piezometric level.

Table. 1. Increase of groundwater extraction rhythm through time (according to Tartari and Dakoli, 2001).

\begin{tabular}{cccc}
\hline & $\begin{array}{c}\text { Pumped } \\
\text { groundwater (1/s) }\end{array}$ & $\begin{array}{c}\text { Self flowing } \\
\text { groundwater }(1 / \mathrm{s})\end{array}$ & $\begin{array}{c}\text { Total groundwater } \\
\text { extraction }\end{array}$ \\
\hline 1983 & 1105 & 410 & 1515 \\
1993 & 1328 & 246 & 1574 \\
\hline
\end{tabular}

Table 2. Variation of chlorine content in groundwater, in time (according to Pano and Saraçi, 2000).

\begin{tabular}{lccc}
\hline Chlorine content $\left(\mathrm{Cl}^{-}\right)$ & Year 1984 & Year 1999 & Year 2001 \\
\hline Well 341 & 1136 & 1008 & 1037 \\
Well 503 & 961 & 1070 & 1048 \\
\hline
\end{tabular}

\section{PEDOLOGICAL HAZARDS}

The agricultural soil in the Kurbini plain is affected by the following hazards: (i) erosion, (ii) floods, (iii) contamination, (iv) acidification, (v) urbanisation, (vi) water saturation, (vii) desertification, (viii) salinization.

The only soil erosion process in the Kurbini plain is recorded along the river banks and reaches over 9.0 t/ha/year (Gjoka and Cara, 2003). The process accelerated recently due to intensive excavation of the alluvial sediments of the river.

Contamination. The previous studies (Salillari, 2006) found that the soil in the neighbourhood of the old metallurgical plant of Laçi (now closed down) are contaminated with heavy metals such as $\mathrm{Cu}, \mathrm{Zn}, \mathrm{Ni}, \mathrm{As}$ and $\mathrm{Pb}$. Their contents range within the following intervals:
$<0.1-1.16 \mathrm{mg} / \mathrm{kg}, 64-541 \mathrm{mg} \mathrm{kg}, 74.20-185.10 \mathrm{mg} / \mathrm{kg}$ and $32.00-565.80 \mathrm{mg} / \mathrm{kg}$ for $\mathrm{Cd}, \mathrm{Zn}, \mathrm{Cr}$ and $\mathrm{Cu}$, respectively. However, the highest contents $(\mathrm{Cu}=18,000 \mathrm{mg} / \mathrm{kg}, \mathrm{Pb}>80$ $\mathrm{mg} / \mathrm{kg}$, As $=30-110 \mathrm{mg} / \mathrm{kg}$ ) were recorded in soil at $100-$ $200 \mathrm{~m}$ distance from the metallurgical plant walls.

Acidification of the soil was related with the activity of the metallurgical plant of Laçi which launched into air tons of $\mathrm{CO}_{2}, \mathrm{SO}_{2}$, etc, that, in turn, have precipitated as acid rains $(\mathrm{pH}=4.5-6.5)$. The acid precipitations destroyed the vegetation around the metallurgical plant and, in particular, along the south-western slopes of the Shullazi village.

Land urbanisation. The demographic movement, from the mountainous regions towards coastal and plain areas, were accompanied by an extensive urbanisation. As a consequence, about 555 ha of agricultural land were converted to housing development areas where over 1,100 houses have been built. These caused the decay of more than 2,200 m of watering channels.

Water saturation represents a widespread and expanded phenomenon in the plain areas of Kurbini. It leads to the formation of the swampy lands on more than 832 ha. The main sources of the water are the precipitations, the groundwater, the irrigation water, and the floods. The transformation of the agricultural land to swamps can be avoid and remediate by an efficient drainage network.

Desertification of soil, that happens when the agricultural land is covered by sand and gravel alluvia (Feiznia et al., 2001), has reduced the surface of the productive land. In the Kurbini region the sandy soils occupy a surface of 950 ha which tends to be expanded due to erosion and flood processes. The monitoring of this process aims to prohibit its further advancement towards the neighbour agricultural soils by reducing the slope erosion and/or avoiding plain floods.

Salinization. Soil productivity is strongly threatened by salinization, i.e. the accumulation of water-soluble salts. This process affects the crops by limiting their ability to take up water. The salinization process may naturally occur or because the bad management of the land. It is mainly 
developed in the coastal low plains where it covers about 500 ha. Salt originates probably from groundwater, sea water, irrigation water, farming practices, etc. The salinization has deteriorated the physical - chemical characteristics of the soil and it has diminished their productivity.

\section{CONCLUSIONS}

Several risk factors are recorded in the Kurbini Plain. Among these, the most important and with highest impact on humans are: flooding, deterioration of the groundwater quality, soil erosion, soil contamination and acidification, land urbanisation, soil desertification and salinization. Most of them have affected the plain areas, while the soil erosion is the only process which has modelled the hilly and mountainous relief. They differ from each other in both intensity and expansion. Their continuous control and management will attenuate and, in some cases, avoid the negative impacts they have on the local community and on their properties.

\section{R E F E R E N C E S}

Beqiraj, A., Masi, U. \& Barbieri, M. 2002, Geochemical and isotopic characteristics of groundwater from TiranaFushe Kuqe basin and implications for its quality. In International Symposium: Administration of Internal and Marine Waters in Albania. Special edition, p. 48-49, Elbasan, Albania.

Eftimi, R., Tafilaj, I. \& Bisha, G. 1989, Hydrogeological features of Albania. Buletini i Shkencave Gjeologjike, 4: 303-316.
Feiznia, S., Gooya, A.N., Ahmadi, H. \& Azarnivand, H. 2001, Investigation on desertification factors in HosseinAbad Mish Mast plain and a proposal for a regional model. Journal of Biaban, 6: 1-14.

Gjoka, F., Cara, K. 2003, Soils of Albania. National Library, Tirana 134 p. (in Albanian).

Kacimov, A.R., Obnosov, Y.V. 2001, Analytical solution for a sharp interface problem in sea water intrusion into a coastal aquifer. Proceedings of Royal Society of London A, 457 (2016): 3023-3038.

Marabini, F. 1985, Evolutional trend of the Adriatic Coast (Italy). In Proceedings volume of IVth Symposium on Coastal and Ocean Management, p. 428-439.

Melo, V., Shallo, M. 1991, Thrusting tectonite within Albanian geolgical structures. Buletini $i$ Shkencave Gjeologjike, 1: 15-28.

Pano, N. 1981, Hydrology of Albania. Hydrometeorology Institute of Albania, Tirana. $287 \mathrm{p}$.

Pano, T., Saraçi, M. 2000, Monitoring of groundwater contamination in Fushe Kuqe aquifer (unpubl.). Archives of Geological Survey of Albania, Tirana (in Albanian), $55 \mathrm{p}$.

Salillari, I. 2006, Contamination of soil by heavy metals in the Laçi region. Monograph UBT Library, Tirana, 158 p.

Sulçe, S., Beqiraj, A., Gjoka, F., Lamaj, M., Pano, N. \& Cenameri, M. 2006, Goverment project: Integral assesment of hazards and the contol of their impacts. Ministry of Envirmonment of Albania, Tirana, $91 \mathrm{p}$.

Suljoti, V., Cenameri, M., Salillari, I. \& Dushaj, L. 2002, Project: LUPP2 (Land Use Policy Project) (unpubl.). Soil Research Institute, Tirana.

Tartari, M., Dakoli, H. 2001, Hydrogeological report of the Tirana-Lezha basin (unpubl.). Archives of Geological Survey of Albania, Tirana (in Albanian), 76 p. 